\title{
Changes in the Stability of a Human H3 Histone mRNA during the HeLa Cell Cycle
}

\author{
TIMOTHY D. MORRIS, ${ }^{1,2}+$ LEE A. WEBER, ${ }^{3}$ EILEEN HICKEY, ${ }^{3}$ GARY S. STEIN, ${ }^{2}$ AND JANET L. STEIN ${ }^{2 *}$ \\ Department of Immunology and Medical Microbiology, University of Florida, Gainesville, Florida $32610^{1}$; Department of \\ Cell Biology, University of Massachusetts Medical School, Worcester, Massachusetts $01655^{2}$; and Departments of \\ Biology and Biochemistry and Molecular Biology, University of South Florida, Tampa, Florida $33602^{3}$
}

Received 14 May 1990/Accepted 16 October 1990

\begin{abstract}
A major component of the regulation of histone protein synthesis during the cell cycle is the modulation of the half-life of histone mRNA. We have uncoupled transcriptional and posttranscriptional regulation by using a Drosophila hsp70-human $\mathrm{H3}$ histone fusion gene that produces a marked human $\mathrm{H3}$ histone mRNA upon heat induction. Transcription of this gene can be switched on and off by raising and lowering cell culture temperatures, respectively. HeLa cell lines containing stably integrated copies of the fusion gene were synchronized by double thymidine block. Distinct populations of $\mathrm{H3}$ histone mRNA were produced by heat induction in early S-phase, late S-phase, or $\mathrm{G}_{2}$-phase cells, and the stability of the induced $\mathrm{H}_{3}$ histone $\mathrm{mRNA}$ was measured. The $\mathrm{H3}$ histone mRNA induced during early $S$ phase decayed with a half-life of $110 \mathrm{~min}$, whereas the same transcript induced during late $S$ phase had a half-life of 10 to $15 \mathrm{~min}$. The $\mathrm{H3}$ histone mRNA induced in non-S-phase cells is more stable than that induced in late $S$ phase, with a half-life of 40 min. Thus, the stability of histone mRNA is actively regulated throughout the cell cycle. Our results are consistent with an autoregulatory model in which the stability of histone mRNA is determined by the level of free histone protein in the cytoplasm.
\end{abstract}

Histone protein synthesis is modulated by the availability of histone mRNA for translation. Both transcriptional and posttranscriptional mechanisms ensure that the levels of mRNAs transcribed from the replication-dependent histone genes increase and decrease in concert with increasing and decreasing rates of DNA synthesis (reviewed in references 23,33 , and 38).

In synchronous mammalian cells, histone mRNA levels rise and fall 10 - to 20 -fold as the cells transit the $S$ phase, while histone mRNA transcription varies only 3- to 5-fold (3, $14,31,40)$. The discrepancy between the extent of the changes in histone mRNA synthesis and the wider fluctuation in histone mRNA abundance strongly implies that posttranscriptional mechanisms play a major role in histone gene regulation. Some of the basic elements of the posttranscriptional regulation of histone mRNA have been elucidated in the past few years. The stem-loop structure found at the $3^{\prime}$ end of all replication-dependent histone mRNAs has been implicated in two different posttranscriptional regulatory mechanisms. Schümperli and co-workers have reported that these sequences are involved in a regulated processing step that keeps histone mRNA levels low in resting $G_{1} / G_{0}$ cells and contributes to the rapid rise in histone mRNA levels as cells begin proliferative growth $(19,42,43)$. The stem-loop sequences have also been shown to play a role in the regulation of mRNA stability. RNA transcripts that have the stem-loop at the $3^{\prime}$ end are targeted for degradation when DNA synthesis is halted $(16,27)$, via a mechanism that requires ongoing protein synthesis $(2,6,40,46)$.

Ross et al. have described a nuclease activity that degrades histone mRNA in a similar manner in vitro and in vivo (34-36). Histone mRNAs are first attacked at the $3^{\prime}$

\footnotetext{
* Corresponding author.

$\dagger$ Present address: Department of Entomology, University of Georgia, Athens, GA 30602.
}

terminus and then degraded processively toward the 5 ' end. The nuclease activity coisolates with polysomes, suggesting that it is closely associated with mRNA in vivo (34-36). In addition, it has been reported that histone mRNA must be translated appropriately in order to be destabilized. Mutational analysis has shown that if translation is terminated more than 300 nucleotides prior to the usual termination codon (13) or between the natural stop codon and the stem-loop sequences (7), normal control of stability is abrogated. A report that the degradation of histone mRNA in vitro is enhanced by the addition of histone proteins and a high-speed cytoplasmic supernatant (29) lends support to autoregulatory models of histone gene expression $(1,6,29$, 45).

Although it is well documented that the half-life of histone mRNAs in cells treated with DNA synthesis inhibitors is approximately $15 \mathrm{~min}(2,9,10,14)$, direct evidence for changes in the stability of histone mRNA during the cell cycle has been difficult to obtain. DeLisle et al. (9), using a pulse-chase method with serum-stimulated mouse 3T6 fibroblasts, estimated the histone $\mathrm{H} 2 \mathrm{~B}$ and $\mathrm{H} 3$ mRNA S-phase half-life to be 4 to $5 \mathrm{~h}$. Alterman et al. (1) synchronized mouse erythroleukemia cells by centrifugal elutriation and used hybridization to measure pulse-labeled $\mathrm{H} 3$ histone mRNA levels synthesized during early and late $S$ phase. In both late $S$ and $G_{2}$ phases, the turnover of labeled $H 3$ histone mRNA was represented by a two-component decay curve. In late $\mathrm{S}$ phase, $50 \%$ of the $\mathrm{H} 3$ histone mRNA decayed with an apparent half-life of $25 \mathrm{~min}$ and the remainder decayed with a 92 -min half-life. $G_{2}$-phase cells turned over $80 \%$ of the mRNA with a $32-$ min half-life and the remaining $20 \%$ with a half-life of $108 \mathrm{~min}$. Heintz et al. (14) estimated from the kinetics of approach to steady-state labeling that the halflives of human histone $\mathrm{H} 2 \mathrm{~A}, \mathrm{H} 3$, and $\mathrm{H} 4 \mathrm{mRNAs}$ in HeLa cells were approximately $40 \mathrm{~min}$ in both asynchronous 


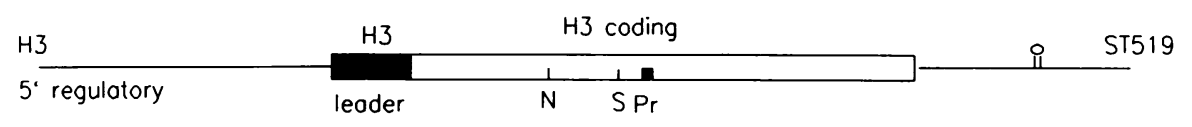

\begin{tabular}{|c|c|c|c|c|c|}
\hline hsp70 & hsp70 & $\mathrm{H3}$ & $\mathrm{H} 3$ coding & 8 & SP1519431 \\
\hline $5^{\prime}$ regulatory & & & $1 \quad 1 n$ & & \\
\hline
\end{tabular}

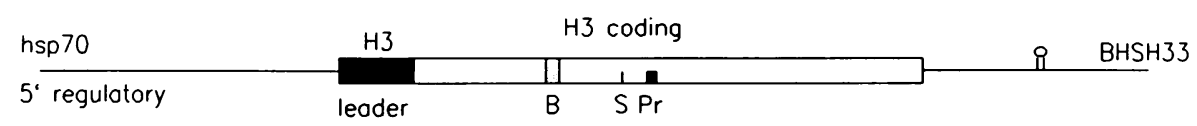

FIG. 1. Comparison of the structure of ST519, SP1519H3L, and BHSH33 genes. Symbols: $\square$, H3 histone protein-coding sequences; , H3 histone leader sequences; 'IIIIIII, hsp70 leader sequences; $\square$, primer-binding sequences; S, SmaI site; N, NaeI site; B, BamHI linker inserted into BHSH33. The mRNA terminal stem-loop structure is represented at the $3^{\prime}$ end of each gene.

exponentially growing cultures and synchronized S-phase cells.

The wide variation in the half-lives obtained in these studies may be due to the limitations of the procedures used. The accuracy of methods used in these studies (pulse-chase and approach to steady-state labeling) depends to a great extent on constant rates of transcription and constant rates of decay during the experiments. Because histone mRNA regulation may involve simultaneous modulation of both transcription and mRNA stability, these approaches may not accurately measure the histone mRNA half-life.

In this study we have directly assayed H3 histone mRNA decay rates during the HeLa cell cycle. Our general experimental approach was as follows. The synthesis of a human $\mathrm{H} 3$ histone gene (21) transcript was placed under the control of an inducible heat shock promoter; cell lines containing stably integrated copies of the fusion gene were constructed; and $\mathrm{H} 3$ histone mRNA was induced in early S-phase, late $\mathrm{S}$-phase or $\mathrm{G}_{2}$-phase cells by mild heat shock and mRNA decay was measured. Our results indicate that the stability of human $\mathrm{H} 3$ histone mRNA changes during the cell cycle, showing a half-life of $110 \mathrm{~min}$ in early S-phase cells, 10 to 15 minutes in late $S$-phase cells, and $40 \mathrm{~min}$ in $G_{2} / M / G_{1}$ cells. These results are consistent with an autoregulatory model in which the stability of histone mRNA throughout the cell cycle is determined by the level of free histone protein in the cytoplasm.

\section{MATERIALS AND METHODS}

Construction of plasmids. The structure of the human $\mathrm{H} 3$ histone gene cloned in pST519 (22) and the two heat shockinducible derivatives used in this study are shown in Fig. 1. Construction of pSP1519H3L has been described previously (25). The gene carried by this plasmid contains the $5^{\prime}$ regulatory elements and the initial 89 nucleotides (nt) of the leader sequence from a Drosophila hsp70 gene fused with the pSP1519 histone gene from which the 5'-flanking sequences and the first $20 \mathrm{nt}$ of the mRNA leader have been deleted.

Plasmid BHSH33 produces a complete human $\mathrm{H} 3$ histone mRNA transcript that has been modified only by insertion of a BamHI linker and is under the control of a heat shock promoter. It was constructed by inserting an 850-bp HinfIHpaI fragment from pST519 into the BamHI site of the pUC8 polylinker. This fragment contains $\mathrm{H} 3$ histone sequences from $\mathrm{nt}-30$ (including the histone TATA box) to +820 (nt +820 is 311 nt $3^{\prime}$ of the normal mRNA terminus). A 286-bp Drosophila heat shock gene fragment (nt -334 to -48) was inserted into the pUC8 EcoRI site so that the heat shock consensus sequences (nt -64 to -48 [44]) were positioned 23 bp 5 ' of the histone TATA box. A 12-bp BamHI linker was then inserted at the NaeI site at nt +129 of the histone-coding sequence, inserting four additional amino acids after codon 30 .

Cell culture, synchrony, and heat shock. HeLa cells were grown in suspension culture at a density of $3 \times 10^{5}$ to $6 \times 10^{5}$ cells per $\mathrm{ml}$ in Joklik modified Eagle minimal essential medium supplemented with $7 \%$ calf serum. Cells were synchronized by two successive treatments with $2 \mathrm{mM}$ thymidine by the method of Stein and Borun (44). Rates of DNA synthesis were determined by pulse-labeling cells with $\left[{ }^{3} \mathrm{H}\right]$ thymidine as previously reported (2). Heat shock induction was accomplished by swirling the culture flask in 60 to $65^{\circ} \mathrm{C}$ water until the culture temperature reached $41^{\circ} \mathrm{C}$. The culture flask was then placed on an air-powered magnetic stir plate immersed in a circulating $41.5^{\circ} \mathrm{C}$ water bath. A thermometer was placed directly in the medium to monitor the culture temperature. The temperature variation during the heat shock was $\pm 0.3^{\circ} \mathrm{C}$. To end the heat shock, the culture flask was swirled in 16 to $18^{\circ} \mathrm{C}$ water until the culture temperature dropped to $38^{\circ} \mathrm{C}$ and then was placed on a stir plate in a $37^{\circ} \mathrm{C}$ warm room.

Establishment of stably transformed cell lines. Transfection was performed essentially by the method of Gorman et al. (11). The calcium phosphate-DNA complex was prepared as described by Graham and van der Eb (12), with $19 \mu \mathrm{g}$ of pSP1519H3L or pBHSH33 and $1 \mu \mathrm{g}$ of pSV2neo (41). Cells expressing the neo gene were selected as described by Southern and Berg (41), with geneticin (G418; GIBCO) at $500 \mu \mathrm{g} / \mathrm{ml}$. Single resistant colonies were expanded and tested for heat-inducible expression of the introduced fusion genes. Lines that exhibited reasonable expression were induced and treated with hydroxyurea (HU) to ensure that the induced $\mathrm{H} 3$ histone mRNA was destabilized normally when DNA synthesis was inhibited. A line exhibiting these 
characteristics was expanded and used in the cell cycle experiments presented here. For large-scale experiments, the cells were adapted to suspension culture in Joklik modified Eagle minimal essential medium supplemented with $5 \%$ fetal calf serum and 5\% horse serum.

RNA isolation and analysis. RNA was isolated as described by Plumb et al. (31). S1 nuclease assays were carried out by the method of Berk and Sharp (4) as modified by Lichtler et al. (17). A ${ }^{32} \mathrm{P}-5$ '-end-labeled genomic DNA fragment extending from the EcoRI site at nt -850 to the $S m a$ I site at nt +170 was used as a probe (Fig. 1). Hybridization reaction mixtures containing $5 \mu \mathrm{g}$ of total cellular RNA and 12,000 cpm of probe were heated at $90^{\circ} \mathrm{C}$ for $10 \mathrm{~min}$ and then annealed at $53^{\circ} \mathrm{C}$ for $3 \mathrm{~h}$. S1 nuclease digestions $(225 \mathrm{U}$ per tube) were incubated at $37^{\circ} \mathrm{C}$ for $30 \mathrm{~min}$.

Primer extension analysis was carried out by using a 20-nt synthetic primer (5'-ACAGTGCCCGGGCGGTAACG-3') complementary to $\mathrm{nt}+160$ to +180 of ST519 (Fig. 1). The primer ( 5 to $10 \mathrm{ng},{ }^{32} \mathrm{P}-5^{\prime}$-end labeled to a specific activity of $1.5 \times 10^{8}$ to $3 \times 10^{8} \mathrm{cpm} / \mu \mathrm{g}$ ) was mixed with 10 to $15 \mu \mathrm{g}$ of total cellular RNA in $10 \mu \mathrm{l}$ of $0.4 \mathrm{M} \mathrm{NaCl}-10 \mathrm{mM}$ piperazine$N, N^{\prime}$-bis(2-ethanesulfonic acid) (PIPES; pH 6.4) and heated for $10 \mathrm{~min}$ at 85 to $90^{\circ} \mathrm{C}$. The reaction tubes were then directly immersed in a $45^{\circ} \mathrm{C}$ water bath to hybridize for $2 \mathrm{~h}$. The reactions were quick cooled in ice-water and diluted by the addition of deoxynucleoside triphosphates (to $1.5 \mathrm{mM}$ each) and $100 \mu \mathrm{l}$ of ice-cold reverse transcriptase buffer (50 $\mathrm{mM}$ Tris hydrochloride [pH 8.3], $6 \mathrm{mM} \mathrm{MgCl}_{2}, 40 \mathrm{mM} \mathrm{KCl}$ ). Avian myeloblastosis virus reverse transcriptase $(25 \mathrm{U} / 5 \mu \mathrm{g}$ of RNA; Life Sciences) was added, and the reaction mixture was incubated at $37^{\circ} \mathrm{C}$ for 45 to $60 \mathrm{~min}$. The nucleic acids were purified by one phenol-chloroform-isoamyl alcohol $(25: 24: 1)$ extraction and then precipitated with ethanol in the presence of $3 \mu \mathrm{g}$ of glycogen as the carrier. The reaction products were analyzed by electrophoresis on $6 \%$ polyacrylamide gels containing $8 \mathrm{M}$ urea (21). The gels were dried under vacuum and exposed to Kodak XAR-5 preflashed film for 5 to 14 days with a Cronex Lightning-Plus intensifying screen. Densitometric analysis was performed by using an LKB-Pharmacia high-intensity laser densitometer. Data collected by the densitometer were processed by using the GelScan XL computer program (LKB-Pharmacia).

In vitro transcription with nuclei isolated from heatshocked cells and the conditions used for hybridization to plasmid DNA containing specific human heat shock protein inserts have been described previously (37). The plasmids used to detect specific heat shock mRNAs were pHS208 (hsp27), pHS601 (hsp60), pHS709 (hsp70), and pHS801 (hsp89) (15).

\section{RESULTS}

Cell cycle dependent changes in ST519 H3 histone mRNA abundance. Most studies of cell-cycle-dependent changes in histone mRNA abundance have involved Northern (RNA) blot analysis $(3,14,31,40)$. Because there is considerable homology between the different histone mRNA species of a given type $(31,48)$, this assay detects multiple histone mRNA species. To establish that the ST519 H3 histone gene exhibits DNA replication-dependent regulation, we measured the abundance of ST519 gene-specific mRNA during the cell cycle by using $\mathrm{S} 1$ nuclease protection analysis (Fig. 2). HeLa cells were synchronized by donble thymidine block, and hourly time points were taken after release from the second block. S1 nuclease analysis of RNA samples by using a 5'-end-labeled probe derived from pST519 yielded

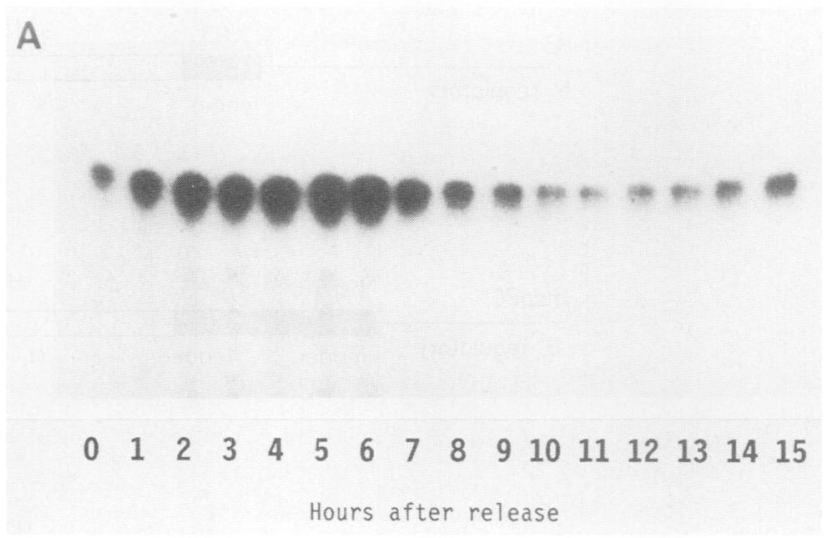

B.

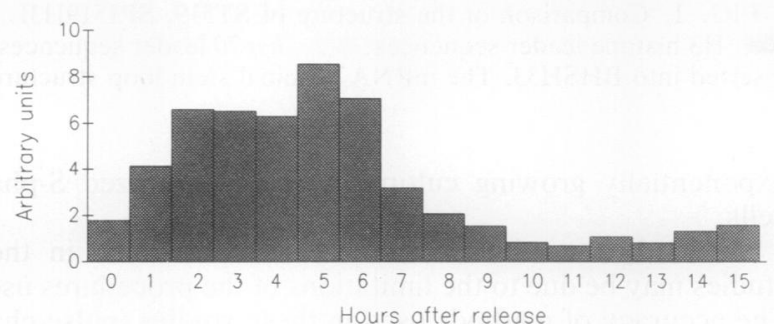

FIG. 2. S1 analysis of ST519 $\mathrm{H} 3$ histone mRNA levels during the cell cycle. Cells were synchronized by double thymidine block, and total cellular RNA was prepared from aliquots taken at 1-h intervals after release from DNA synthesis inhibition. (A) A 5- $\mu \mathrm{g}$ sample of RNA from each time point was hybridized with $12,000 \mathrm{cpm}$ of a ${ }^{32} \mathrm{P}-5$ '-end-labeled EcoRI-SmaI fragment derived from ST519, digested with S1 nuclease, and analyzed by gel electrophoresis as described in Materials and Methods. (B) Densitometric quantitation of the autoradiogram shown in panel $\mathrm{A}$.

protected fragments that correspond to the mRNA start sites of the gene (data not shown). ST519 mRNA levels peaked approximately $5 \mathrm{~h}$ after release, during mid-S phase (Fig. 2A). Densitometric analysis of multiple autoradiographic exposures indicated that ST519 mRNA levels in mid-S phase are 10 -fold higher than in the $G_{1} / G_{2}$ phase (Fig. $2 B$ ). Numerous reports have shown that $\mathrm{H} 3$ histone transcription rises only an average of three- to fivefold during the $S$ phase (3, $14,31,40)$, an increase that cannot entirely account for the fluctuations in histone mRNA levels. We have asked whether significant variations in ST519 mRNA stability during the cell cycle can be directly demonstrated and whether these changes correlate with changes in $\mathrm{H} 3$ mRNA synthesis rates in a manner that can account for both the 10-fold increase and the 10-fold decrease in ST519 mRNA levels as the cells transit the $S$ phase.

Construction of heat-inducible histone genes. To eliminate the transcriptional cell cycle influence of the normal ST519 promoter, we constructed fusion genes in which the ST519 promoter was replaced by a Drosophila hsp70 promoter (Fig. 1). The constructs included a marker sequence so that the induced transcripts could be distinguished from endogenous ST519 mRNA in HeLa cells by primer extension analysis (see Materials and Methods for construction details). The untranslated leader of the SP1519H3L transcript contains 89 nt derived from the Drosophila hsp70 untranslated leader and the last $20 \mathrm{nt}$ of the ST519 H3 histone 
mRNA leader. The SP1519H3L fusion gene is identical to the ST519 gene throughout the protein-coding region, the 3' untranslated region, and the $3^{\prime}$ sequences required for proper transcriptional termination and processing (42). The BHSH33 fusion gene codes for a transcript identical to ST519 mRNA except for the insertion of $12 \mathrm{nt}$ in the coding region at codon 30 (which preserves the translational reading frame). The SP1519H3L and BHSH33 transcripts are thus 69 and $12 \mathrm{nt}$ longer, respectively, than ST519 mRNA and can be easily distinguished from ST519 mRNA by primer extension analysis.

Transcription from the hsp70 promoter during the cell cycle. Because the Drosophila hsp70-human histone fusion gene transcripts differ only slightly from the endogenous human $\mathrm{H} 3$ histone mRNAs, direct measurements of transcription from the fusion gene promoter by using standard in vitro nuclear run-on assays are not feasible. However, a number of studies have indicated that human $h s p 70$ and Drosophila $h s p 70$ genes are similarly regulated in human cells $(5,18,20,25) . h s p 70$ promoter elements are well conserved between human and Drosophila cells (18), and both promoters compete effectively for a human nuclear heat shock factor (20). The regulated expression of Drosophila hsp70 transcription has been demonstrated in mouse, monkey, frog, and human cells $(5,25)$. Therefore we have studied the transcriptional regulation of the endogenous human $h s p 70$ gene, making the reasonable assumption that in human cells the heat shock regulatory machinery uses both the human and Drosophila hsp 70 promoters in a similar manner.

As our experimental strategy was to use heat shock induction to create similar fusion gene mRNA populations in synchronized cells, it was important that induction of transcription from the $h s p 70$ promoter proceeds similarly in different phases of the cell cycle. HeLa cells were synchronized by double thymidine block, and aliquots of cells were heat shocked at specific times after release. Northern blot analysis indicated that the kinetics and the level of induction of endogenous human $h s p 70$ mRNA are comparable in both the $S$ and $G_{2} / G_{1}$ phases (data not shown). Milarski et al. (24) recently reported similar results with cells synchronized by mitotic detachment as part of a detailed study of the influence of the cell cycle on the heat shock response. In addition to confirming the cell-cycle-independent induction of the $h s p 70$ gene, we have determined that transcription from the hsp70 promoter can be effectively switched on by a moderate temperature increase and abruptly switched off by rapid cooling to the normal culture temperature. In vitro nuclear run-on transcription analysis (Fig. 3) shows that transcription of all the major classes of human heat shock genes is strongly induced within $10 \mathrm{~min}$ after a shift to $42^{\circ} \mathrm{C}$. After 90 min of heat shock, cooling to $37^{\circ} \mathrm{C}$ reduces the transcription rate to near pre-heat shock levels within $30 \mathrm{~min}$. These data indicate that the $h s p 70$ promoter can be used to produce a population of mRNAs in a cell cycle-independent manner which, once transcription has been down-regulated, is controlled primarily by posttranscriptional mechanisms.

Stability of SP1519H3L and BHSH33 mRNAS in HUtreated cells. To determine whether the induced populations of $\mathrm{H} 3$ histone mRNAs are posttranscriptionally regulated in the same manner as normal $\mathrm{H} 3$ histone mRNAs, we investigated the stability of these transcripts in human cells following HU treatment. HU inhibits DNA synthesis and thereby causes the rapid degradation of replication-dependent histone mRNAs $(2,6,10)$. Cell lines containing stably integrated copies of the SP1519H3L or BHSH33 fusion

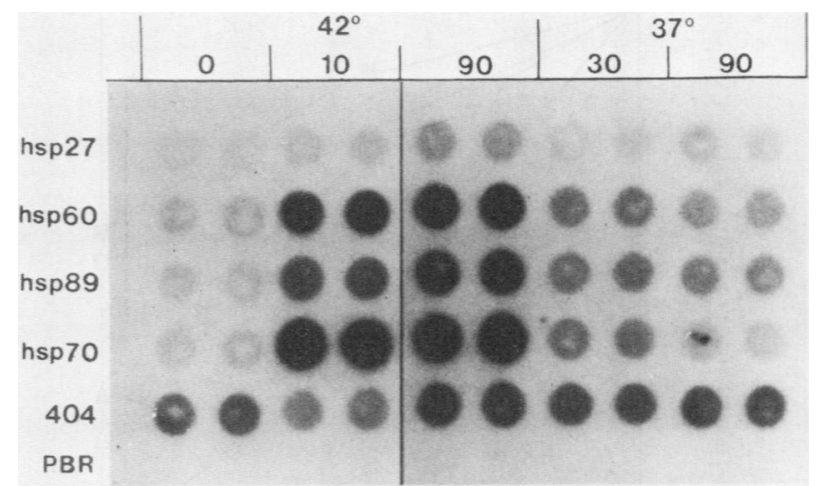

FIG. 3. Heat shock gene transcription during heat shock and after return to $37^{\circ} \mathrm{C}$. HeLa cells were heat shocked at $42^{\circ} \mathrm{C}$ and returned to $37^{\circ} \mathrm{C}$ for the indicated times. Nuclei were isolated, and in vitro run-on transcription was carried out as described in Materials and Methods. The radioactive transcripts were then hybridized to a filter containing duplicate $10-\mu \mathrm{g}$ aliquots of recombinant plasmids specific for each class of human heat shock mRNA and autoradiographed. CP404 is an abundant control mRNA that is not affected by heat shock (38). PBR is a vector DNA control.

genes were heated to $41.5^{\circ} \mathrm{C}$ for $90 \mathrm{~min}$ and then rapidly cooled to $37^{\circ} \mathrm{C}$ and maintained for $60 \mathrm{~min}$ before $\mathrm{HU}$ treatment. RNA isolated from cells harvested at specific times after HU treatment was analyzed by primer extension assay. The relative amounts of SP1519H3L and BHSH33 mRNA in HU-treated cells were determined by densitometry and compared with the amounts of these mRNAs in untreated control cells (Fig. 4). The SP1519H3L and BHSH33 mRNA levels, along with endogenous ST519 mRNA levels, are reduced to a similar extent (60 to $80 \%)$ by HU treatment. The levels of both chimeric mRNAs decline more slowly in control cells not treated with HU. These data indicate that both SP1519H3L and BHSH33 mRNAs are subject to histone mRNA-specific, posttranscriptional control. The additional sequences used to mark the induced mRNAs ( $h s p 70$ mRNA 5' untranslated sequences in SP1519H3L mRNA and the BamHI linker inserted in the coding region of BHSH33 mRNA) do not significantly affect normal histone mRNA posttranscriptional regulation.

In a previous report (25) we showed that SP1519H3L mRNA levels were not significantly reduced in cells treated with $\mathrm{HU}$ during continuous incubation at $42^{\circ} \mathrm{C}$. However, in the present study we found that if cells are heat shocked for $90 \mathrm{~min}$ and allowed to recover from heat treatment for 30 to $60 \mathrm{~min}$ at $37^{\circ} \mathrm{C}$ and then treated with $\mathrm{HU}, \mathrm{SP} 1519 \mathrm{H} 3 \mathrm{~L}$ mRNA levels are drastically reduced. The reasons for the dissimilar results yielded by different heat shock procedures will be addressed below.

H3 histone mRNA stability during the cell cycle. To examine the role of regulated changes in $\mathrm{H} 3$ histone mRNA stability in cell cycle-dependent regulatory mechanisms, we induced distinct populations of human $\mathrm{H} 3$ histone mRNA in synchronized cells during different cell cycle phases. The rates at which induced $\mathrm{H} 3$ histone mRNA levels declined were directly compared and correlated with the DNA synthetic status of the cells in which the mRNAs were induced.

Cells containing stably integrated copies of the BHSH33 fusion gene were synchronized by double thymidine block. DNA synthesis rates were monitored hourly in control (constant $37^{\circ} \mathrm{C}$ ) and heat-shocked cells by $\left[{ }^{3} \mathrm{H}\right]$ thymidine incorporation (Fig. 5). Aliquots of cells were taken at 1, 4.75, 


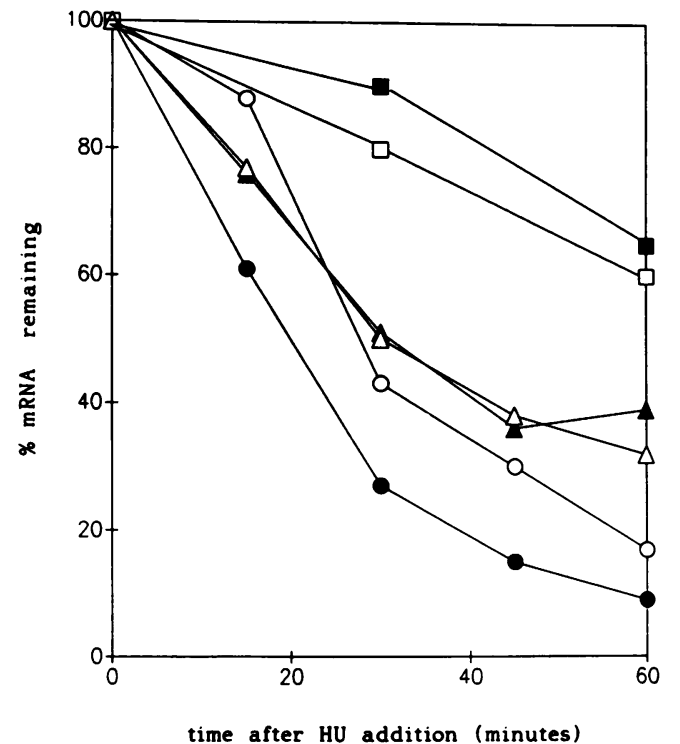

FIG. 4. Degradation of SP1519H3L and BHSH33 mRNAs in HU-treated cells. Cell cultures were heat shocked at $41.5^{\circ} \mathrm{C}$ for $90 \mathrm{~min}$ and cooled rapidly to $37^{\circ} \mathrm{C}$. After $60 \mathrm{~min}$ at $37^{\circ} \mathrm{C}$, half of each culture was removed and treated with $\mathrm{HU}(2 \mathrm{mM})$; aliquots were removed at $15,30,45$ and 60 min after HU addition. A 10- $\mu \mathrm{g}$ sample of total cellular RNA from each time point was analyzed by primer extension assay. The relative amount of each mRNA present in treated and untreated cells was determined by densitometric analysis of multiple autoradiographic exposures. Symbols: $\square$, SP1519H3L mRNA levels in untreated cells; $\Delta$, SP1519H3L mRNA levels in HU treated cells; 9 , endogenous ST519 mRNA in HUtreated cells; $\square$, BHSH33 mRNA levels in untreated cells; $\triangle$, BHSH33 mRNA levels in HU treated cells; $\bigcirc$, endogenous ST519 mRNA in HU-treated cells.

and $8 \mathrm{~h}$ after release from the thymidine block, heat shocked for $90 \mathrm{~min}$ (Fig. 5) and then cooled to $37^{\circ} \mathrm{C}$. Heat treatment at the specified times after release would induce synthesis of distinct histone mRNA populations in the early $S$ phase, when DNA synthesis rates are increasing, in the late $S$ phase, when DNA synthesis rates are decreasing, and in the $\mathrm{G}_{2}$ phase, when DNA synthesis rates are low and constant. Following the early S-phase heat shock, DNA synthesis increased normally after a 1-h delay. After the late S-phase heat shock, the normal decline in DNA synthesis was also delayed for about $1 \mathrm{~h}$. DNA synthesis following the $G_{2}$-phase heat shock was not significantly different from the non-heatshock control rate.

The level of BHSH33 histone mRNA in the heat-treated cells was measured by primer extension assay over the intervals indicated by arrows in Fig. 5. The primer used is complementary to $\mathrm{nt}+160$ to +180 of ST519 mRNA. Because the BHSH33 mRNA is marked by the insertion of a 12-nt BamHI linker at nt +129 (Fig. 1), primer extension products from the recombinant $\mathrm{BHSH} 33 \mathrm{mRNA}$ are $12 \mathrm{nt}$ longer than extension products from natural ST519 mRNA. The BHSH33 mRNA is detected only in heat-shocked cells (Fig. 6A). In early S phase, significant levels of BHSH33 mRNA are still apparent in cells $3.5 \mathrm{~h}$ after cessation of the heat shock (Fig. 6B). BHSH33 mRNA does not accumulate to comparable levels following heat shock in late S-phase cells (Fig. 6C), and it decays more rapidly. Levels of BHSH33 mRNA similar to those produced in early S-phase cells were induced in $G_{2}$-phase cells. However, the mRNA

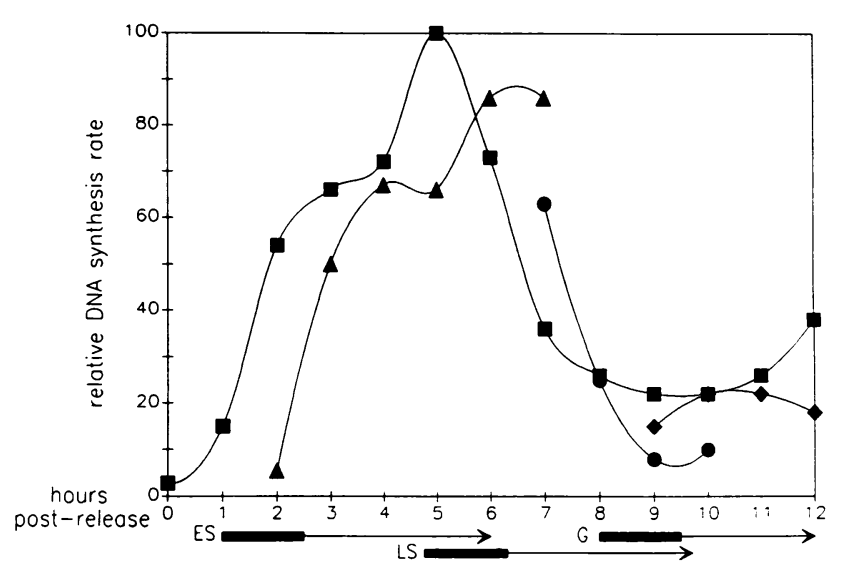

FIG. 5. DNA synthesis rates in synchronized cells after heat shock. A BHSH33 cell culture was synchronized by double thymidine block. At 1, 4.75, and $8 \mathrm{~h}$ after release from the second thymidine block, aliquots of synchronized cells were removed, heat shocked at $41.5^{\circ} \mathrm{C}$ for $90 \mathrm{~min}$, and then rapidly cooled to $37^{\circ} \mathrm{C}$ (the duration of heat shock is represented by the bars at the bottom of the figure). DNA synthesis rates were measured by determining the incorporation of $\left[{ }^{3} \mathrm{H}\right]$ thymidine into trichloroacetic acid-precipitable counts during 30 -min pulses. Symbols: $\mathbf{\square}, 37^{\circ} \mathrm{C}$ control cells; $\boldsymbol{\Delta}$, early S-phase heat shock, cells held at $41.5^{\circ} \mathrm{C}$ from 1 to $2.5 \mathrm{~h}$ postrelease; $\bullet$, late S-phase heat shock, cells heat shocked from 4.75 to $6.25 \mathrm{~h}$ after release; $\diamond, \mathrm{G}_{2}$-phase heat shock, cells heat shocked from 8 to $9.5 \mathrm{~h}$ after release.

synthesized during the $G_{2}$ phase decays more rapidly than that synthesized during early $S$ phase (Fig. 6D). Shorter autoradiographic exposures show that the levels of natural H3 histone (ST519) mRNA follow normal cell cycle patterns in these experiments (data not shown).

The decay of the BHSH33 mRNA was quantified by densitometry and is displayed graphically in Fig. 7. Linear regression analysis indicates that the kinetics of $\mathrm{BHSH} 33$ mRNA decay are significantly different during each phase of the cell. Early $S$-phase and $G_{2}$-phase cells each display a single decay rate during the periods analyzed, yielding estimated half-lives of 110 and $40 \mathrm{~min}$, respectively. In late S-phase cells, the decay rate shows two separate components: approximately $50 \%$ of the BHSH33 mRNA in late S-phase cells decays with a maximal half-life of $15 \mathrm{~min}$, whereas the remaining mRNA appears to decay at a rate similar to the rate in $G_{2}$-phase cells. This second component may result from a subpopulation of the cells that have already moved from the late $S$ phase into the $G_{2}$ phase. Thus, the stability of $\mathrm{H} 3$ histone mRNA varies widely during the cell cycle. The mRNA is most stable when DNA synthesis rates are increasing (early $S$ phase), is least stable when DNA synthesis is decreasing (late $S$ phase) and has an intermediate stability when DNA synthesis rates are low and constant $\left(\mathrm{G}_{2}\right.$ phase and possibly the second component of late $S$-phase decay).

H3 histone mRNA stability in asynchronously proliferating cells. The conclusion that $\mathrm{H} 3$ histone mRNA exhibits different decay rates during the cell cycle is also indicated by an examination of the fate of endogenous and heat shockinduced mRNA following inhibition of DNA synthesis in asynchronous cultures. Cells containing stably integrated copies of the SP1519H3L gene were heat shocked continuously for $3 \mathrm{~h}$. After $2 \mathrm{~h}$ of heat shock, HU was added to the culture to stop DNA synthesis, and the levels of the endogenous ST1519 H3 histone mRNA and the SP1519H3L tran- 


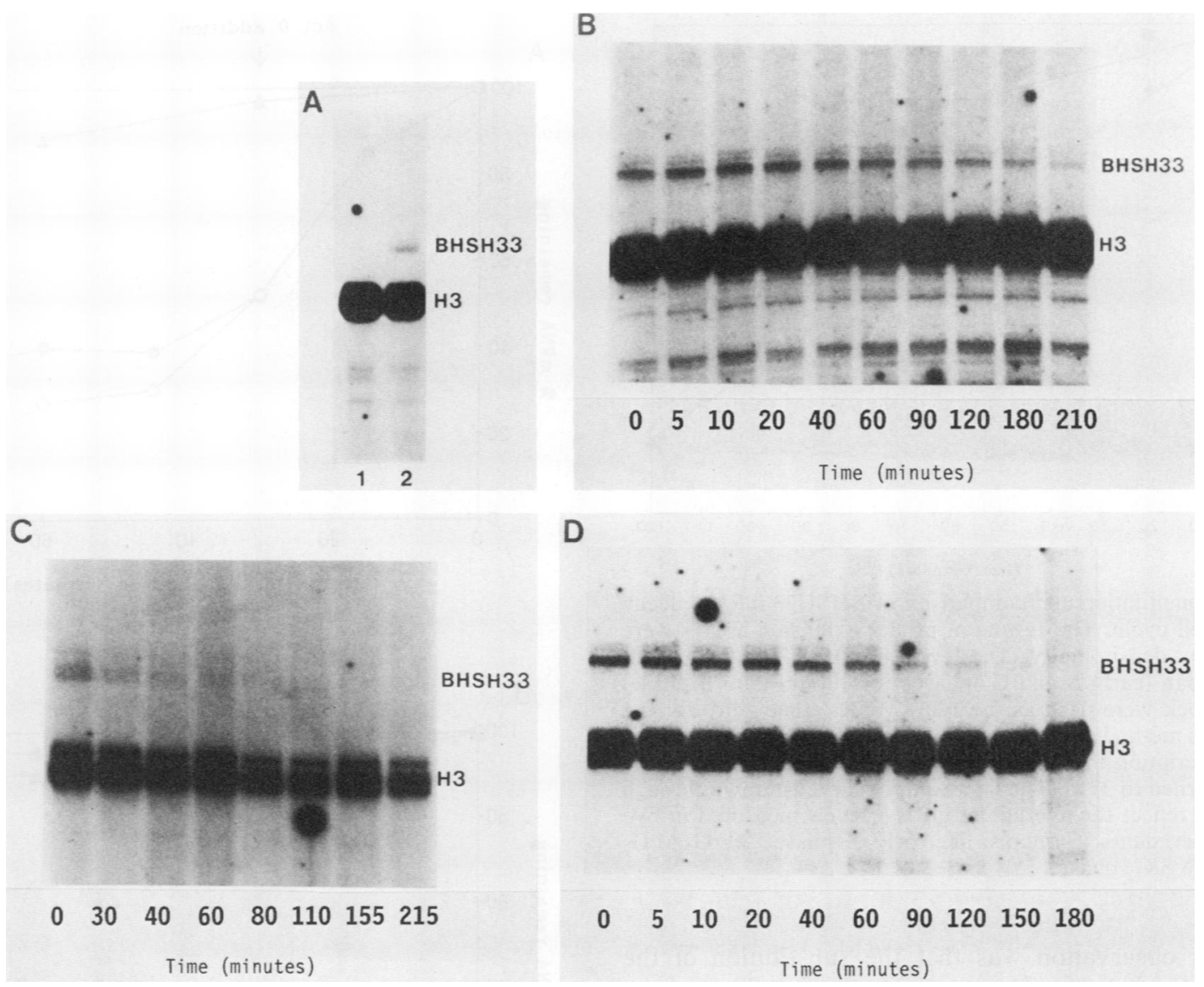

FIG. 6. Stability of BHSH33 mRNA during different phases of the cell cycle. (A) An asynchronous BHSH33 cell culture was tested for inducible expression of marked $\mathrm{H} 3 \mathrm{mRNA}$. A $10-\mu \mathrm{g}$ sample of total cellular RNA was analyzed by primer extension assay. Lanes: $1,37^{\circ} \mathrm{C}$ incubation; 2,90 -min incubation at $41.5^{\circ} \mathrm{C}$. (B to D) A BHSH33 cell culture was synchronized by double thymidine block. At $1,4.75,8 \mathrm{~h}$ after release from the second thymidine block, aliquots of synchronized cells were removed, heat shocked at $41.5^{\circ} \mathrm{C}$ for 90 min, and then rapidly cooled to $37^{\circ} \mathrm{C}$. Cells were harvested at the specified time points following each cooling. The levels of BHSH33 and ST519 (H3) mRNAs were determined by primer extension analysis with $10 \mu \mathrm{g}$ of total cellular RNA. The lanes are labeled to indicate the time after the end of the heat shock at which cells were harvested. Panel B shows BHSH33 mRNA levels during early S phase. Time zero is $2.5 \mathrm{~h}$ after release. Panel C shows BHSH33 mRNA decay during late $S$ phase. Time zero is $6.5 \mathrm{~h}$ after release. Panel D shows $B_{H S H} 33 \mathrm{mRNA}$ decay during the $\mathrm{G}_{2} / \mathrm{M} / \mathrm{G}_{1}$ phase. Time zero is $9.5 \mathrm{~h}$ after release.

script were measured over a period of $75 \mathrm{~min}$ by primer extension. Heat shock had little effect on the level of the endogenous histone mRNA over the course of the experiment (Fig. 8A). However, endogenous ST519 mRNA levels rapidly declined when $\mathrm{HU}$ was added. After $45 \mathrm{~min}$ of exposure to HU, the loss of ST519 mRNA appeared to slow, even when the cells were subsequently treated with dactinomycin $30 \mathrm{~min}$ after addition of $\mathrm{HU}$. In contrast, the level of SP1519H3L mRNA was not affected by HU treatment (Fig. 8B). However, when dactinomycin was added to block transcription of the fusion gene after $30 \mathrm{~min}$ of $\mathrm{HU}$ treatment, approximately $40 \%$ of the SP1519H3L mRNA decayed rapidly during the initial $20 \mathrm{~min}$ (Fig. 8B). After this time, the remaining mRNA decayed much more slowly.

The observed biphasic decay curves are consistent with the cell cycle-specific differences in histone mRNA stability that we have measured. According to our data, histone mRNA in cells in which DNA synthesis rates are low (outside the $S$ phase) would decay with a half-life of $40 \mathrm{~min}$, a rate which would presumably remain unchanged in the presence of HU. Therefore, in an asynchronous culture, HU treatment will destabilize only the fraction of the histone
mRNA population in cells actively synthesizing DNA (i.e., in the $S$ phase). The two-phase decay curves in Fig. 8 are consistent with a higher rate of decay in HU-treated S-phase cells and a lower rate of decay in non-S-phase cells. Most (80 to $90 \%$ ) of the endogenous ST519 H3 histone mRNA resides in S-phase cells (Fig. 2), and thus the bulk of the endogenous H3 histone mRNA would be destabilized by HU. Because SP1519H3L mRNA is induced by heat shock equally in all cell cycle phases (24), less than $50 \%$ of the SP1519H3L mRNA in the culture would be expected to reside in S-phase cells. The difference in the cell cycle phase distribution of these mRNAs is reflected in the amount of each mRNA remaining in the culture when the decay curves plateau at approximately $40 \mathrm{~min}$ after $\mathrm{HU}$ addition (Fig. 8). Additional experiments in which cells were pretreated with dactinomycin and then exposed to HU yielded similar two-component decay curves (data not shown).

We had previously found that when an asynchronous SP1519H3L cell culture is treated with HU during a continuous heat shock, there is no significant decrease in SP1519H3L mRNA levels, even though endogenous ST519 mRNA is rapidly destabilized (25). Our previous interpreta- 


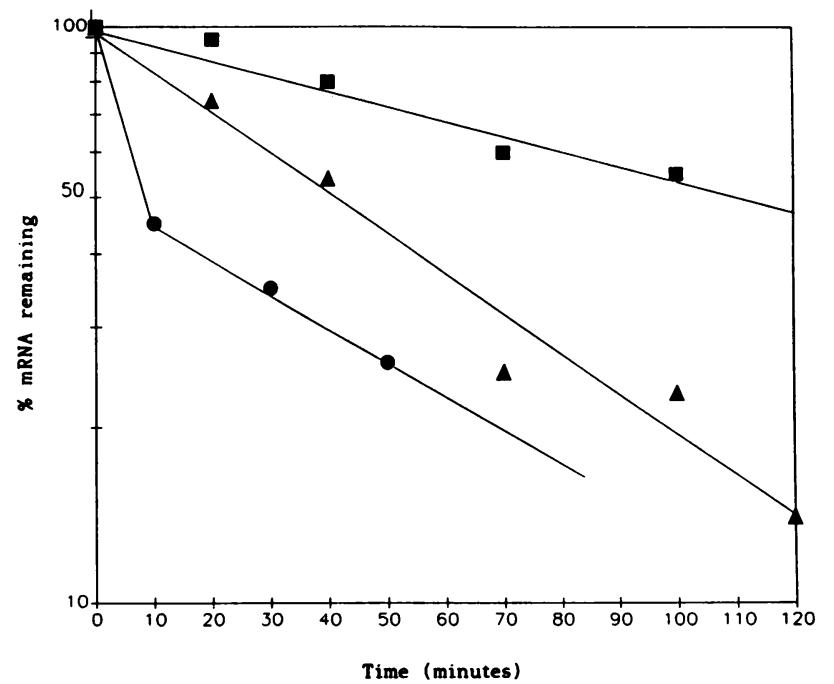

FIG. 7. Quantitation and comparison of BHSH 33 mRNA decay during the cell cycle. The results of primer extension assays were quantitated by densitometry. The levels of BHSH33 mRNA measured at $20 \mathrm{~min}$ (early $S$ and $G_{2}$ phases) or 30 min (late $S$ phase) post-heat shock were used as the $100 \%$ values (time zero) for the analysis. This method ensured that the decay curves are not skewed by any transcription that might continue for a short time after the cells are returned to $37^{\circ} \mathrm{C}$. The late-S-phase curve is drawn through points which reflect the average of mRNA levels measured in two

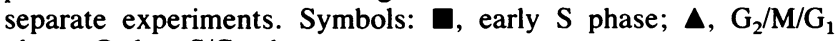
phase; $\boldsymbol{Q}$, late $S / G_{2}$ phase.

tion of this observation was that the substitution of the Drosophila hsp70 leader sequences for the first $20 \mathrm{nt}$ of the ST519 leader in SP1519H3L stabilized the resulting fusion mRNA. However, the additional data in this report indicate that other factors are responsible for the persistence of SP1519H3L mRNA levels in HU-treated, continuously heatshocked cells. First, SP1519H3L gene transcription during a continuous heat shock appears to play a role in masking the HU-induced turnover of SP1519H3L mRNA. When heat shock-induced SP1519H3L transcription is terminated either by dactinomycin treatment (Fig. 8A) or by cooling the culture to $37^{\circ} \mathrm{C}$ (Fig. 4), SP1519H3L mRNA levels rapidly decline when DNA synthesis is inhibited. Second, as described above, about $50 \%$ of the induced mRNA in an asynchronous culture is in non-S-phase cells and therefore is not rapidly destabilized during HU treatment.

\section{DISCUSSION}

We have directly measured the decay rates of a human $\mathrm{H} 3$ histone mRNA during the cell cycle. We found that $\mathrm{H} 3$ histone mRNA turns over at three distinct rates, which correlate with cell cycle-dependent changes in DNA synthesis. When DNA synthesis rates are increasing in the early $S$ phase, $\mathrm{H} 3$ histone mRNA decays with an apparent half-life of 110 min. During the late $\mathrm{S}$ phase, when the synthesis of DNA is in rapid decline, the mRNA is destabilized with an apparent half-life of 10 to $15 \mathrm{~min}$. Non-S-phase cells, in which DNA synthesis rates are low and constant, turn over H3 histone mRNA with an apparent half-life of $40 \mathrm{~min}$.

Previous estimates of histone mRNA S-phase half-lives have ranged from $25 \mathrm{~min}$ to $5 \mathrm{~h}(1,9,14,30,31)$. This wide range of values may reflect cell type differences (9), heterogeneity in the regulation of different histone mRNA species,
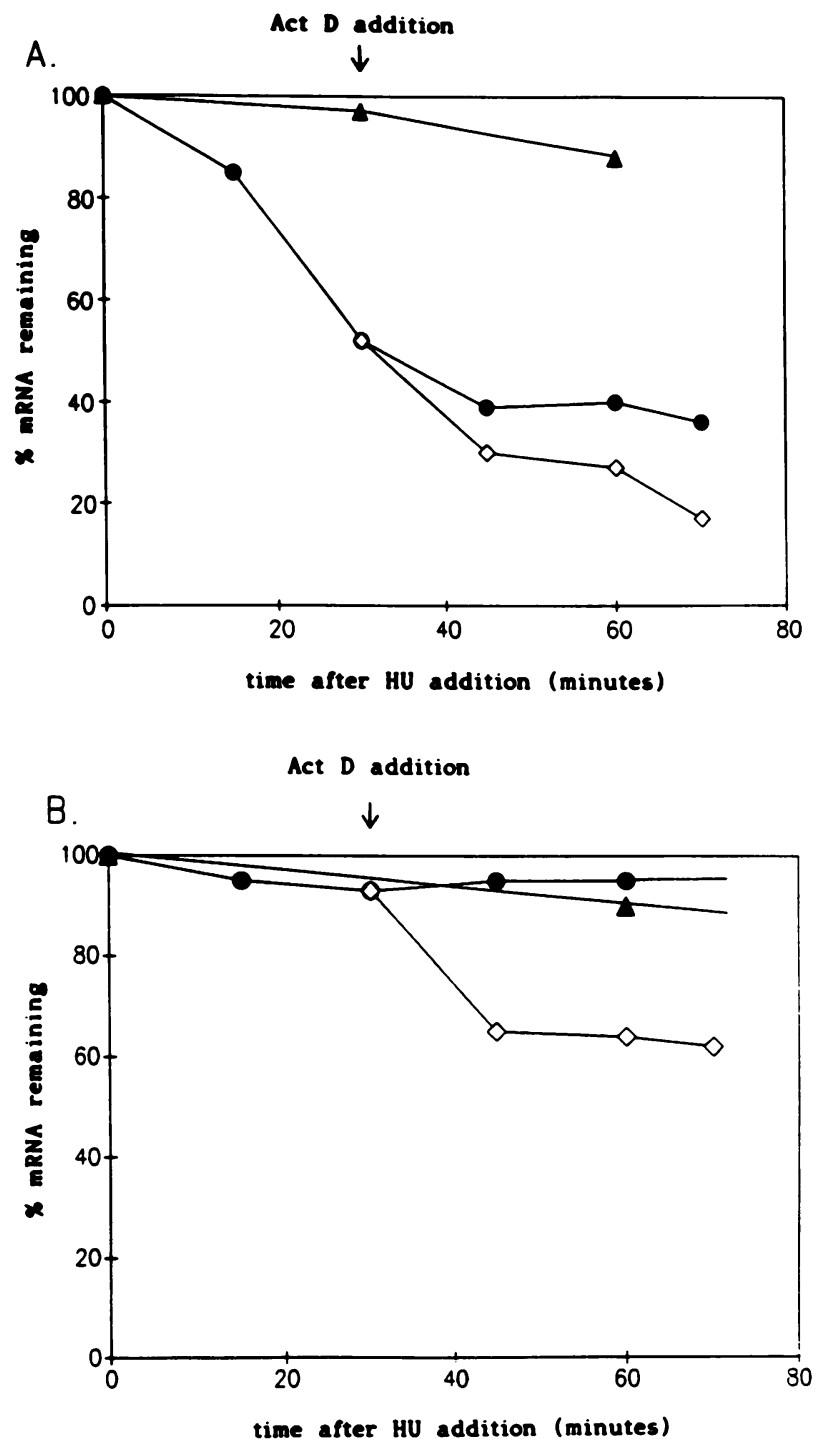

FIG. 8. Stability of SP1519H3L and ST'519 mRNA in an asynchronous culture during continuous heat shock. An exponentially growing SP1519H3L culture was heat shocked at $41.5^{\circ} \mathrm{C}$. After the first $2 \mathrm{~h}$ of heat shock, a portion of the culture was treated with HU ( $2 \mathrm{mM}) ; 30 \mathrm{~min}$ later, a portion of the HU-treated culture was also treated with $5 \mu \mathrm{g}$ of dactinomycin (Act D) per ml. RNA was isolated from each of the three separate cultures at the times indicated, and the levels of SP1519H3L and ST519 mRNAs were determined by primer extension analysis. The amounts of SP1519H3L and ST519 mRNAs detected at $2 \mathrm{~h}$ after the start of heat shock are used as the $100 \%$ values. (A) ST519 mRNA levels. (B) SP1519H3L mRNA levels. Symbols: $\triangle$, mRNA levels in cells that were heat shocked only; $\bullet$, mRNA levels in HU-treated cells; $\bullet$, mRNA levels in heat-shocked cells treated with HU and dactinomycin.

or differences in the analytical methods that were used. The labeling techniques used in previous studies have significant drawbacks in an experimental system as dynamic as synchronized cell cultures. For such systems, the usual assumptions concerning rapid nucleotide pool equilibration, efficient chases, and uniform histone mRNA synthesis and decay are more difficult to justify. By utilizing an inducible histone gene and direct mRNA analysis, we have attempted to 
circumvent some of the potential problems inherent in these earlier techniques.

The substitution of an $h s p 70$ promoter for the normal $\mathrm{H} 3$ histone gene promoter eliminates cell cycle-dependent histone transcriptional influences. Thermal induction of transcription in suspension cells is uniform, rapid, and easily controlled. Decay rate determinations are based on direct assay of mRNA levels by primer extension. A possible drawback of our system was that heat shock might significantly perturb normal histone mRNA metabolism. However, we chose a mild heat shock protocol, which induced measurable levels of fusion gene mRNA while leaving normal histone regulatory mechanisms intact.

Our results suggest that ST519 $\mathrm{H} 3$ histone mRNA is 2.5 - to 3-fold more stable in early $S$ phase than in the $G_{2} / M / G_{1}$ phase. The stability of the mRNA drops 7- to 10 -fold as the cells move from the mid-S phase into the late S phase. ST519 mRNA abundance increases 10 -fold during early $S$ phase and then drops 10 -fold in late $S$ phase. This 10 -fold fluctuation is easily accounted for by combining the changes in stability we have assayed with the cell cycle-dependent three- to fivefold variation in histone mRNA synthesis widely reported in the literature $(3,14,31,40)$.

Our finding that histone mRNA has an apparent half-life of $40 \mathrm{~min}$ in cells outside the $\mathrm{S}$ phase has significant implications for models of histone mRNA regulation. An intermediate decay rate in cells in which DNA synthesis rates are quite low suggests that decay rates do not correlate with absolute rates of DNA synthesis but rather with both positive and negative changes in DNA synthesis rates. In addition, this result implies that regulation of stability is not accomplished by a degradative pathway that is simply deactivated at the beginning of the $S$ phase and reactivated at the end of the $S$ phase. The significance of this finding in terms of a general model for histone posttranscriptional control will be explored below.

In previous reports $(9,10,14,23,38)$, it has been suggested that the rapid decline of histone mRNA levels in S-phase cells treated with DNA synthesis inhibitors may be closely analogous to the rapid loss of histone mRNA that occurs at the end of the $S$ phase when DNA synthesis is naturally terminated. Our data support this long-standing assumption. The apparent $10-$ to $15-\mathrm{min}$ histone mRNA half-life we have measured in the late $S$ phase is in close agreement with reports of 10 - to 15 -min histone mRNA half-lives after the inhibition of DNA synthesis by drug treatment $(2,9,10,14,32)$.

The basic elements of the cytoplasmic posttranscriptional regulation of histone mRNA abundance are threefold: (i) the specific identification of histone mRNA; (ii) a nuclease that degrades histone mRNA when required; and (iii) a signal that couples DNA synthesis rates with mRNA levels. In recent years, significant progress has been made in identifying and characterizing both the histone mRNA targeting sequences $(15,19,26,42,43)$ and the nuclease involved in histone mRNA degradation (29, 34-36) (see Introduction). Little is known about the signal(s) that links changes in DNA synthesis rates in the nucleus with changes in the abundance of histone mRNA in the cytoplasm.

An autoregulatory model, originally proposed in 1973 by Butler and Mueller (6) and expanded by others (34, 45, 49), suggests that histone proteins themselves provide the link between DNA synthesis and histone mRNA abundance. Direct evidence in support of such a role for histone proteins is found in a report by Peltz and Ross (29), which demonstrates that the degradation of histone mRNA in vitro is enhanced four- to sixfold by the addition of histone proteins and a high-speed cytoplasmic supernatant.

A major prediction of the autoregulatory model is that histone mRNA stability should change significantly during the cell cycle. Our data appear to confirm this prediction. The direct regulatory interaction of histone protein(s) with histone mRNA in a probabilistic manner could account for the wide range of histone mRNA stabilities we have observed. Models involving a degradative switch, involving degradative mechanisms that are either fully active or fully inactive, could not easily account for the intermediate rates of decay we have measured in $G_{2} / M / G_{1}$-phase cells.

A simple explanation of our data in terms of a probabilistic autoregulatory model is that the longevity of a histone mRNA during any phase of the cell cycle is determined by the probability that it will encounter free histone protein(s) in the cytoplasm. During the $G_{2} / M / G_{1}$ phase, when DNA synthesis rates are minimal and constant, a relatively small amount of new histone protein is required, possibly to bind to stretches of repaired DNA and to replace chromatinassociated histones lost at normal rates of histone protein turnover. The synthesis of histone mRNA continues at low but significant rates. histone mRNA pools are held at a relatively low and constant level by the establishment of an equilibrium between the addition of newly synthesized histone mRNA and the level of unused histone protein which triggers histone mRNA degradation. Because histone transcription provides more mRNA than is needed to meet the low demand for histone protein, an excess of histone protein is produced. Any histone mRNA in the pool has a $50 \%$ chance of encountering a free histone protein during any 40-min period (hence an apparent half-life of $40 \mathrm{~min}$ ).

This equilibrium is radically perturbed as the cells enter the $\mathrm{S}$ phase. Histone mRNA synthesis rises three- to fivefold, and, simultaneously or soon after, DNA synthesis rates rapidly increase. The demand for new histone proteins to associate with newly replicated DNA outstrips production, ensuring that very little free cytoplasmic histone protein remains to feed back onto histone mRNAs in the cytoplasm. The chances that a histone mRNA will encounter free histone protein(s) are slight. Histone mRNAs appear to be maximally stable, with an apparent half-life of $110 \mathrm{~min}$.

Finally, when DNA synthesis rates begin to drop as the cells near the end of the $S$ phase, histone protein synthesis is in vast excess of utilization, and it becomes very likely that a histone mRNA will come into contact with free histone protein(s). The apparent half-life drops 7- to 10-fold, to 10 to $15 \mathrm{~min}$. When most of the excess mRNA is degraded, the original $G_{2}$-phase equilibrium is reestablished.

The simplicity of this model is attractive. One need not invoke separate mechanisms to stabilize mRNA in early $S$ phase and then to destabilize it in late $S$ phase. The constitutive nuclease activity that appears to be a part of the polysomal mRNA-protein complex and the role of the targeting $3^{\prime}$ stem-loop structure are easily incorporated into the model. The final driving force behind this complex pattern of regulation may depend simply on the association constant of the interaction between free histone protein and histone mRNA containing polysomes.

\section{ACKNOWLEDGMENTS}

We thank Gerard Zambetti and David Collart for helpful discussions and Steve Baker for help with mathematical modeling of histone mRNA populations in asynchronous cells.

These studies were supported by grants from the National Science 
Foundation (DCB88-96116) and the National Institutes of Health (GM32381).

\section{REFERENCES}

1. Alterman, R. M., S. Ganguly, D. H. Schulze, W. F. Marzlufi, C. L. Schildkraut, and A. Skoultchi. 1984. Cell cycle regulation of mouse $\mathrm{H} 3$ histone mRNA metabolism. Mol. Cell. Biol. 4:123-132.

2. Baumbach, L. L., F. Marashi, M. Plumb, G. Stein, and J. Stein. 1984. Inhibition of DNA replication coordinately reduces cellular levels of core and $\mathrm{H} 1$ histone mRNAs: requirement for protein synthesis. Biochemistry 23:1618-1625.

3. Baumbach, L. L., G. S. Stein, and J. L. Stein. 1987. Regulation of human histone gene expression: transcriptional and posttranscriptional control in the coupling of histone mRNA stability with DNA replication. Biochemistry 26:6178-6187.

4. Berk, A. J., and P. A. Sharp. 1977. Sizing and mapping of early adenovirus mRNAs by gel electrophoresis of $\mathrm{S} 1$ endonuclease digested hybrids. Cell 12:721-732.

5. Bienz, M. 1985. Transient and developmental activation of heat shock genes. Trends Biochem. Sci. 10:157-161.

6. Butler, W. B., and G. C. Mueller. 1973. Control of histone synthesis in HeLa cells. Biochim. Biophys. Acta 294:481-486.

7. Capasso, O., G. C. Bleeker, and N. Heintz. 1987. Sequences controlling histone H4 mRNA abundance. EMBO J. 6:18251831.

8. Craig, E. A., B. J. McCarthy, and S. C. Wadsworth. 1979. Sequence organization of two recombinant plasmids containing genes for the major heat shock induced protein of D. melanogaster. Cell 16:575-588.

9. DeLisle, A., R. A. Graves, W. F. Marzlufi, and L. F. Johnson. 1983. Regulation of histone mRNA production and stability in serum stimulated mouse 3T6 fibroblasts. Mol. Cell. Biol. 3:1920-1929.

10. Gallwitz, D. 1975. Kinetics of inactivation of histone mRNA in the cytoplasm after inhibition of DNA replication in synchronized HeLa cells. Nature (London) 257:247-248.

11. Gorman, C. M., L. Mofiat, and B. H. Howard. 1982. Recombinant genomes which express chloramphenicol acetyltransferase in mammalian cells. Mol. Cell. Biol. 2:1044-1051.

12. Graham, F. L., and A. J. van der Eb. 1973. A new technique for the assay of infectivity of human adenovirus 5 DNA. Virology 52:456-457.

13. Graves, R. A., N. B. Pandey, N. Chodchoy, and W. F. Marzlufi. 1987. Translation is required for the regulation of histone mRNA degradation. Cell 48:615-626.

14. Heintz, N., H. Sive, and R. G. Roeder. 1983. Regulation of human histone gene expression: kinetics of accumulation and changes in the rate of synthesis and in the half-lives of individual histone mRNAs during the HeLa cell cycle. Mol. Cell. Biol. 3:539-550.

15. Hickey, E., S. Brandon, S. Sadis, G. Smale, and L. A. Weber. 1986. Molecular cloning of sequences encoding the human heat shock proteins and their expression during hyperthermia. Gene 43:147-154.

16. Levine, B. J., N. Chodchoy, W. F. Marzlufi, and A. Skoultchi. 1987. Coupling of replication type histone mRNA levels to DNA synthesis requires the stem-loop sequence at the $3^{\prime}$ end of the mRNA. Proc. Natl. Acad. Sci. USA 84:6189-6193.

17. Lichtler, A. C., F. Sierra, S. Clark, J. Wells, J. L. Stein, and G. S. Stein. 1982. Multiple H4 histone mRNAs of HeLa cells are encoded in different genes. Nature (London) 298:195-198.

18. Lindquist, S. 1986. The heat shock response. Annu. Rev. Biochem. 55:1151-1191.

19. Lüscher, B., and D. Schümperli. 1987. RNA $3^{\prime}$ processing regulates histone mRNA in a mammalian cell cycle mutant. A processing factor becomes limiting in G1-arrested cells. EMBO J. 6:1721-1726.

20. Kingston, R. E., T. J. Schuetz, and Z. Larin. 1987. Heatinducible factor that binds to a human hsp70 promoter. Mol. Cell. Biol. 7:1530-1534.

21. Maniatis, T., E. F. Fritsch, and J. Sambrook. 1982. Molecular cloning: a laboratory manual. Cold Spring Harbor Laboratory,
Cold Spring Harbor, N.Y.

22. Marashi, F., S. Helms, A. Shiels, S. Silverstein, D. Greenspan, G. Stein, and J. Stein. 1986. Enhancer-facilitated expression of prokaryotic and eukaryotic genes using human histone gene 5' regulatory sequences. Biochem. Cell Biol. 64:277-289.

23. Marzlufi, W. F., and N. B. Pandey. 1988. Multiple regulatory steps control histone mRNA concentrations. Trends Biochem. Sci. 13:49-52.

24. Milarski, K. L., W. J. Welch, and R. Morimoto. 1989. Cell cycle-dependent association of hsp70 with specific cellular proteins. J. Cell Biol. 108:413-423.

25. Morris, T., F. Marashi, L. Weber, E. Hickey, D. Greenspan, J. Bonner, J. Stein, and G. Stein. 1986. Involvement of the 5' leader sequence in coupling the stability of a human histone mRNA with DNA synthesis. Proc. Natl. Acad. Sci. USA 83:981-985.

26. Oliver, D., D. Granner, and R. Chalkey. 1974. Identification of a distinction between cytoplasmic histone synthesis and subsequent histone deposition within the nucleus. Biochemistry 13: 746-749.

27. Pandey, N. B., and W. F. Marzluff. 1987. The stem-loop structure at the $3^{\prime}$ end of histone mRNA is necessary and sufficient for regulation of histone mRNA stability. Mol. Cell. Biol. 7:4557-4559.

28. Pelham, H. R. B. 1982. A regulatory upstream promoter element in the drosophila hsp70 heat shock gene. Cell 30:517-528.

29. Pelz, S. W., and J. Ross. 1987. Autogenous regulation of histone mRNA decay by histone proteins in a cell-free system. Mol. Cell. Biol. 7:4345-4356.

30. Perry, R. P. and D. E. Kelley. 1973. Messenger RNA turnover in mouse L cells. J. Mol. Biol. 79:681-696.

31. Plumb, M., J. Stein, and G. Stein. 1983. Coordinate regulation of multiple histone mRNAs during the cell cycle in HeLa cells. Nucleic Acids Res. 11:2391-2410.

32. Plumb, M., J. Stein, and G. Stein. 1983. Influence of DNA synthesis inhibition on the coordinate expression of core human histone genes during S phase. Nucleic Acids Res. 11:7927-7945.

33. Ross, J. 1988. Messenger RNA turnover in eukaryotic cells. Mol. Biol. Med. 5:1-14.

34. Ross, J., and G. Kobs. 1986. H4 histone messenger RNA decay in cell free extracts initiates at or near the $3^{\prime}$ terminus and proceeds $3^{\prime}$ to 5'. J. Mol. Biol. 188:579-593.

35. Ross, J., G. Kobs, G. Brewer, and S. W. Pelz. 1987. Properties of the exonuclease activity that degrades H4 histone mRNA. J. Biol. Chem. 262:9374-9381.

36. Ross, J., S. W. Pelz, G. Kobs, and G. Brewer. 1986. Histone mRNA degradation in vivo: the first detectable step occurs at or near the $3^{\prime}$ terminus. Mol. Cell. Biol. 6:4362-4371.

37. Sadis, S., E. Hickey, and L. A. Weber. 1988. Effect of heat shock on RNA metabolism in Hela cells. J. Cell. Physiol. 135:377-386.

38. Schümperli, D. 1988. Multilevel regulation of replication-dependent histone genes. Trends Genet. 4:187-191.

39. Senshu, T., and M. Ohashi. 1979. Fate of newly synthesized histones shortly after interruption of DNA replication. J. Biochem. 86:1259-1267.

40. Sive, H. L., N. Heintz, and R. Roeder. 1984. Regulation of human histone gene expression during the HeLa cell cycle requires protein synthesis. Mol. Cell. Biol. 4:2723-2734.

41. Southern, P. J., and P. Berg. 1982. Transformation of mammalian cells to antibiotic resistance with a bacterial gene under control of the SV40 early region promoter. J. Mol. Appl. Genet. 1:327-341.

42. Stauber, C., B. Lüscher, R. Eckner, E. Lötscher, and D. Schümperli. 1986. A signal regulating mouse H4 mRNA levels in a mammalian cell cycle mutant and sequences controlling RNA $3^{\prime}$ processing are both contained within the same 80 bp fragment. EMBO J. 5:3297-3303.

43. Stauber, C., and D. Schümperli. 1988. 3' processing of premRNA plays a major role in proliferation-dependent regulation of histone gene expression. Nucleic Acids Res. 16:9399-9414.

44. Stein, G. S., and T. W. Borun. 1972. The synthesis of acidic chromosomal proteins during the cell cycle of HeLa S-3 cells. J. Cell Biol. 52:299-307. 
45. Stein, G. S., and J. L. Stein. 1984. Is human histone gene expression autogenously regulated? Mol. Cell. Biochem. 64: $105-110$.

46. Stimac, E., V. Groppi, and P. Coffino. 1983. Increased histone mRNA levels during inhibition of protein synthesis. Biochem. Biophys. Res. Commun. 114:131-137.

47. Tullis, R. H., and H. Rubin. 1980. Calcium protects DNaseI from proteinase $\mathrm{K}$ : a new method for the removal of contami- nating RNase from DNaseI. Anal. Biochem. 107:260-264.

48. Wells, D. E. 1986. Compilation analysis of histones and histone genes. Nucleic Acids Res. 14:r119-r149.

49. Wu, R. S., and W. M. Bonner. 1985. Mechanism for differential sensitivity of the chromosome and growth cycles of mammalian cells to the rate of protein synthesis. Mol. Cell. Biol. 5:29592966. 